REVIJA ZA ELEMENTARNO IZOBRAŽEVANJE JOURNAL OF ELEMENTARY EDUCATION

Vol. 13, No. 4, pp. 365-394, December 2020

\title{
DIDACTIC TRANSPOSITION OF RATIONAL NUMBERS: A CASE FROM A TEXTBOOK ANALYSIS AND Prospective Elementary Teachers' MATHEMATICAL AND DIDACTIC KNOWLEDGE
}

\author{
Zetra Hainul Putra
}

Potrjeno/Accepted 12. 8.2020

Objavljeno/Published 10. 12.2020

Keywords:

Didactic transposition, hypothetical teacher tasks, mathematical and didactic knowledge, mathematical knowledge to be taught, praxeology, taught knowledge

Ključne besede: didaktični prenos, hipotetične naloge učitelja, matematično in didaktično znanje, predvideno matematično znanje, praksologije, podajano znanje

UDK/UDC

37.091.3:51
University of Riau, Pekanbaru City, Riau, Indonesia

\author{
CORRESPONDING AUTHOR/KORESPONDENČNI AVTOR/ \\ zetra.hainul.puta@lecturer.unri.ac.id
}

\begin{abstract}
Izvleček This study aims to present a detailed analysis of didactic transposition of rational numbers from knowledge to be taught into taught knowledge occurring in a teacher education institution. The knowledge to be taught of rational numbers is analysed from the mathematics textbook used by prospective elementary teachers in a mathematics education course. The analysis focuses on mathematical praxeology, especially the type of task and technique. Then, the taught knowledge is investigated from 32 prospective elementary teachers' collaborative work on two hypothetical teacher tasks (HTT) related to operations with rational numbers.

Didaktični prenos racionalnih števil: primer iz analize učbenika ter matematično in didaktično znanje bodočih učiteljev razrednega pouka Namen študije je predstaviti podrobno analizo didaktičnega prenosa racionalnih števil iz predvidenega znanja $\mathrm{v}$ poučevanje znanja, ki poteka $\mathrm{v}$ instituciji za izobraževanje učiteljev. Znanje racionalnih števil, ki naj bi se poučevalo, analiziramo po učbeniku matematike in ga pri predmetu matematika uporabljajo bodoči učitelji razrednega pouka. Analiza se osredinja na matematične prakseologije, zlasti na tip nalog in tehnik. Posredovano znanje nato proučujemo po sodelovalnih delih 32 bodočih učiteljev na temo dveh hipotetičnih nalog učiteljev (HNU), povezanih z operacijami z racionalnimi števili.
\end{abstract}

\footnotetext{
DOI https://doi.org/10.18690/rei.13.4.365-394.2020

Besedilo / Text (C) 2020 Avtor(ji) / The Author(s)

To delo je objavljeno pod licenco Creative Commons CC BY Priznanje avtorstva 4.0 Mednarodna. Uporabnikom je dovoljeno tako nekomercialno kot tudi komercialno reproduciranje, distribuiranje, dajanje $\mathrm{v}$ najem, javna priobčitev in predelava avtorskega dela, pod pogojem, da navedejo avtorja izvirnega dela. (https://creativecommons.org/licenses/by/4.0/).
}

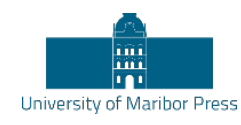




\section{Introduction}

Previous studies on mathematics education have focused on teachers' knowledge and their learning and teaching of rational numbers (Alenazi, 2016; Depaepe et al., 2015; Johar, Patahuddin, \& Widjaja, 2017; Z. H. Putra, 2019a; van Steenbrugge et al., 2014). The reason for concern on this topic is that many students find this subject difficult to learn, nor do teachers know how to teach it. Teachers tend to instruct students based on a standard procedure without knowing the underlying meaning (Putra, 2018; Sembiring, Hadi, \& Dolk, 2008). Putra (2018), for instance, has investigated prospective Indonesian elementary teachers, working with five hypothetical teacher tasks (HTT) about rational numbers. An HT'T is a task based on a teaching situation that may arise at school and allows teachers to use their relevant mathematical and didactic knowledge to act appropriately. Putra (2018) found that most prospective elementary teachers employed a standard technique to solve the mathematical tasks, such as the standard procedure for adding two fractions. The prospective elementary teachers mostly considered those as the only way to teach students about rational numbers. With more advanced tasks, such as the division of fractions, many prospective elementary teachers were unaware of the concept behind the standard procedure. Ma (1999) also found that only few U.S. elementary teachers realised the meaning of division of fractions, and many of them could not explain why the divisor has to be inverted to perform the standard procedure of fraction division.

Beyond the structure of rational numbers, Siegler and Lortie-Forgues (2017) mention that teacher knowledge and the rational number instruction in textbooks become culturally contingent sources of the difficulty. Many previous studies have investigated to what extent teachers understand and know rational numbers (Alenazi, 2016; Depaepe et al., 2015; Johar et al., 2017; Newton, 2008). In the case of division of rational numbers, Alenazi (2016) found that prospective teachers could not provide appropriate interpretations of symbolic problems or construct contextual problems involving fraction division. On the other hand, understanding decimals and their operations was hard for prospective teachers (Graeber, Tirosh, \& Golver, 1989). Specifically on the task of decimal division, the primacy of the partitive division model becomes a source of difficulty because decimal quantities as divisors breach the basic concept that governs partitioning a whole rather than 
finding the number of units of a given value in a given whole (Kastberg \& Morton, 2014; Tirosh \& Graeber, 1989).

Meanwhile, mathematics textbooks often provide students with simple rational number problems, such as to operate fractions with the standard procedure. Wijaya, van den Heuvel-Panhuizen, and Doorman (2015) have found that only a small number of tasks in Indonesian school textbooks provide students with opportunityto-learn mathematical concepts based on real-life contexts. This similar situation could also be the case for textbooks used by prospective Indonesian teachers in initial teacher education. Therefore, this study aims to investigate the mathematical organisation that appears in a textbook used by prospective elementary teachers, and establish to what extent prospective elementary teachers' mathematical and didactic knowledge deals with the operations of rational numbers.

\section{Arithmetic operations of rational numbers}

Proficiency with arithmetic operations of rational numbers is particularly important for learners to learn more advanced mathematics and science, but many children and adults, including teachers, have some difficulty in this domain (Siegler \& LortieForgues, 2017). Several factors have been identified as the causes, including how this topic has been presented in school textbooks (Alajmi, 2012), teachers' knowledge (Depaepe et al., 2015; Hill, Schilling, \& Ball, 2004; Newton, 2008), and the complexity of rational number construction (Charalambous \& Pitta-Pantazi, 2007).

In terms of addition and subtraction of fractions, students often consider the procedure of adding or subtracting fractions as adding natural numbers ( $\mathrm{Li}, 2014)$. They add or subtract the numbers based on their position. The students do not realise that they need to change the technique as well as the theoretical lens from viewing a fraction as two distinct numbers into seeing it as a number as a whole, or what (Putra, 2019b) calls a praxeological change.

A part-whole construction of fractions tends to be used by teachers to explain the task related to adding and subtracting fractions, and it is mostly represented through diagrams. Inaccuracy in using this model can lead students to misinterpret fractions. Austin et al., (2011), focusing their study on the addition of fractions, established some prospective teachers' misconceptions about and misinterpretation of the unit used to add two fractions. 
When the teachers designed a contextual task, they did not realise the importance of two units being the same size and shape when adding fractions. In addition, some of them were unaware of using standard units of measurement rather than informal units, and different measuring units cannot represent the same fractional part.

Theoretical constructions for multiplication and division of rational numbers are much more challenging for many teachers to teach and students to learn. Many students overgeneralise the techniques used in the natural numbers to rational numbers. To deal with this situation, teachers tend to explain the standard procedure for the multiplication of two fractions. They do not elaborate on the various theoretical explanations for multiplication of rational numbers, such as repeated addition, area concept, multiplicative measurement (Isiksal \& Cakiroglu, 2011), and linear mapping (Brousseau, 2002).

The division of rational numbers becomes much more challenging for teachers to explain. Ma (1999), two decades ago, confirmed the difficulty encountered by U.S. teachers in explaining the meaning of standard techniques of fraction division. They could not consider several interpretations of the division of rational numbers, such as sharing or quotative division and measurement or partitive division. Alenazi (2016) also found that many prospective teachers could not link the measurement and unit rate concept to the task of fraction division. This finding indicates that the constructions of the division of fractions or rational numbers has become a challenge for teachers to understand and to instruct pupils within those interpretations.

Concerning multiplication and division of decimals, Graeber and Tirosh (1988) found that prospective teachers' primitive models of multiplication influence their performance in constructing real world problems. They have major challenges in constructing and explaining the multiplication of decimals involving operators less than 1. Although many prospective teachers were perfectly capable of performing operations with decimals, some still used reasoning based on their experience with whole numbers (Graeber \& Tirosh, 1988), such as that one cannot divide by a decimal. In addition, the primacy of the partitive division model becomes a source of difficulty for many students and teachers (Kastberg \& Morton, 2014; Tirosh \& Graeber, 1989). In the present study, I developed and designed two teacher tasks 
based on teachers' difficulties and challenges in learning operations with rational numbers. The first task focuses on teachers' mathematical and didactic knowledge of addition and subtraction of fractions. The second task presents a situation related to students' difficulties with multiplication and division of decimals. The elaboration of the tasks is presented in the Methods section.

\section{Theoretical framework: didactic transposition}

The theoretical framework underpinning this study is the anthropological theory of the didactic (Chevallard, 2006). This theory employs an epistemological and institutional approach to study "didactic phenomena" such as transposition of knowledge. A body of knowledge, such as fractions or rational numbers, taught by teachers at school is initially produced in institutions outside school. This knowledge presented to students has been transformed from the scholarly knowledge produced by mathematicians, to learned knowledge. This is not such a simple process but involves several processes and needs modification during these processes. The model for these processes is known as didactic transposition (Bosch \& Gascón, 2006; Chevallard, 1985). So, didactic transposition is a model for understanding didactic phenomena, such as what knowledge is being taught by teachers at school, how this knowledge has been reconstructed by the education system, and how it is originally produced by scholars or mathematicians.

A simplified model of the process of didactic transposition is presented in Figure 1 (Bosch \& Gascón, 2006; Chevallard \& Bosch, 2014). A body of mathematical knowledge begins from scholarly knowledge produced by mathematicians. This knowledge should be transformed into a form that can be made available to students in the learning institution. It is decided by the noosphere or people in the system, e.g., people working in the ministry of education, curriculum designers, textbook developers, and politicians. The knowledge to be taught is presented in school textbooks, and then teachers play a role in transforming it into taught knowledge. In some cases, the teachers may directly present students with what appears in the textbooks, but it is also possible that changes introduced at this time are caused by the teachers' teaching experiences and their professional knowledge from teacher education programmes. Finally, learned knowledge acquired by students is considered as the end of this didactic transposition. The arrows indicate the causes and effects from one didactic process to the other. 


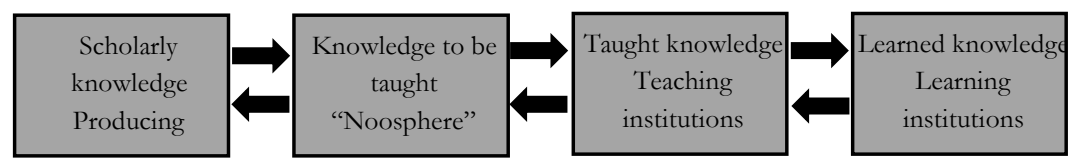

Figure 1: The didactic transposition process in mathematics education (Bosch \& Gascón, 2006)

The body of knowledge to be studied in each process must be well-defined. Chevallard (2006, 2007), through his anthropological theory of the didactic, introduced an epistemological model to analyse human knowledge, and it is known as praxeology. A praxeology is a minimum unit in which one can analyse the human knowledge occurring in a transposition process into two interconnected components: praxis or a practical block, and logos or a knowledge block. The practical block unifies two interrelated components: the type of task (T) to be studied and techniques $(\tau)$ functioning to solve the task. For example, one type of task is adding two fractions, and one of the techniques to solve this task involves changing both fractions into fractions with a common denominator and then adding the numerators. The knowledge block unifies a technology $(\theta)$ used to clarify the techniques and theory $(\Theta)$ to validate several technologies. An example of technology to explain the standard procedure of adding two fractions is based on the rule of adding two fractions through changing both fractions into fractions with a common denominator, and the arithmetic property of adding fractions functions as a general theory to justify this technology. In the present study, I have employed praxeology to analyse the didactic transposition of rational numbers. The study focuses only on knowledge to be taught and taught knowledge (Lundberg \& Kilhamn, 2018; Pansell \& Boistrup, 2018). The knowledge to be taught is investigated through analysing a mathematics textbook for teacher education. The taught knowledge is studied through prospective teachers' collaborative work on two mathematical and didactic tasks about operations with rational numbers. My study focuses on the operations of rational numbers because these have been shown by many studies to be challenging for pupils to learn (Kara \& Incikab1, 2018) and also challenging for teachers to teach (Depaepe et al., 2015; Ma, 1999; van Steenbrugge et al., 2014). Thus, the research questions for this study can be stated as follows:

RQ1. What knowledge to be taught on the arithmetic of rational numbers appears in mathematics textbooks for teacher education? 
RQ2. What taught knowledge is discussed by prospective elementary teachers during their collaborative work?

RQ3. How is the taught knowledge related to the knowledge to be taught?

\section{Methods}

This study is based on a qualitative research method developed within the anthropological theory of the didactic, specifically didactic transposition and praxeology (Chevallard, 2006). The first step is to analyse the praxeology of four arithmetic operations of rational numbers from a mathematics textbook for teacher education. I follow the textbook analysis method from Wijayanti and Winslow's study (2017) by describing the praxeological reference models (PRM) that appear in the textbook. The textbook analysed in this study is an unpublished mathematics textbook written by Putra (2014). This textbook was chosen because prospective elementary teachers use it while taking a course on mathematics education for the upper grades of elementary school (preparing them to teach grades 4 to 6 ) in the elementary teacher education study program in a public university in Riau, Indonesia.

The second, and the essential part, is to analyse prospective elementary teachers' knowledge of the arithmetic operations of rational numbers. The idea is to examine teachers' mathematical and didactic praxeology appearing during their individual and collaborative activities working on HTT about the arithmetic operations of rational numbers (Putra, 2018). The main characteristic of HTT is that prospective elementary teachers are situated in a hypothetical situation where students experience the difficulties and challenges of learning the arithmetic operations of rational numbers. So, they are encouraged to solve this problem and are asked to share their mathematical and didactic knowledge with their pairs.

The first HTT is about addition and subtraction of fractions, and the second is about multiplication and division of decimals (Figure 2). I present two different rational number representations to yield broader insights into prospective elementary teachers' knowledge of rational numbers. The two tasks presented in this study were part of Putra's previous studies (Putra, 2018), and HT'T 2 was adapted from TEDSM studies (Senk et al., 2012). HTT 1 consists of three tasks. 
The first task examines prospective elementary teachers' mathematical knowledge; the second task is to let them individually analyse incorrect answers from imaginary students (e.g., adding both numerators and both denominators), and finally, they are asked to discuss their answers given in support of the students' learning process. HTT 2 directly leads prospective elementary teachers to work collaboratively to handle students' difficulties with multiplication and division. Didactic transposition plays an important role in describing the connection between knowledge to be taught and taught knowledge. The knowledge to be taught is viewed from the praxeological analysis of rational numbers appearing in the textbook. Then, the taught knowledge is studied from the praxeological analysis of prospective elementary teachers' mathematical and didactic knowledge of operations with rational numbers.

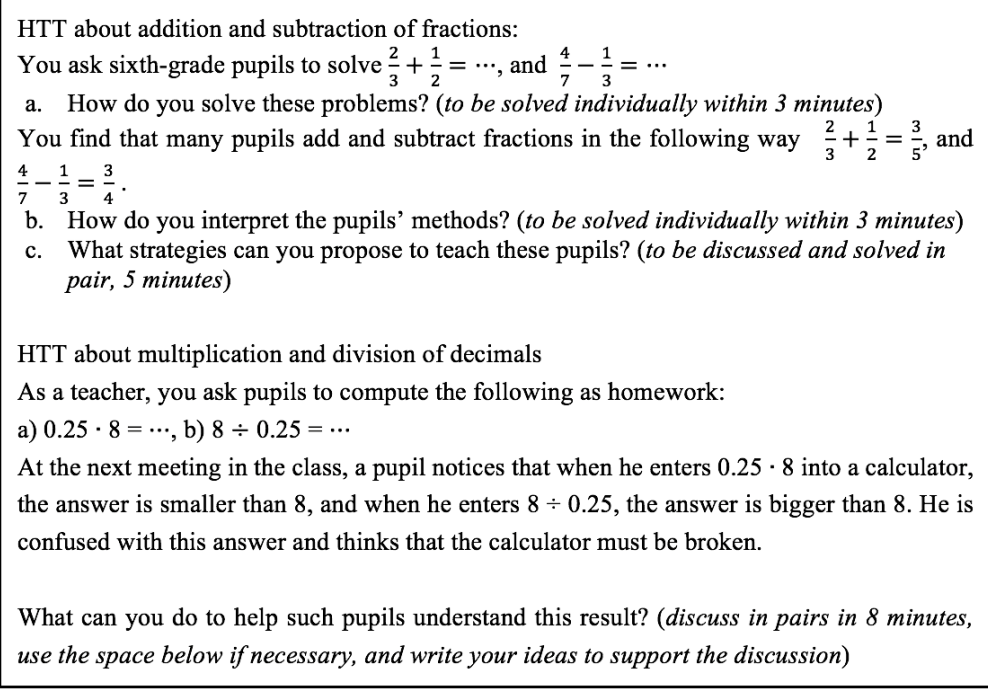

Figure 2: Two HTT's about operations with rational numbers.

The participants of this study were 32 fourth-year prospective elementary teachers working in pairs and coming from the elementary teacher education study program (7 males and 25 females, Mean age $=21.8$ years, $\mathrm{SD}=0.57)$. These prospective elementary teachers volunteered to participate in the study based on their desire to learn about and to help the researcher learn more about operations with rational numbers. The researcher sought permission from all participants before they agreed to participate in this study and informed them that their information provided was 
confidential, and their names were anonymous. In addition, we renamed all pairs from group 1 to group 16, and two prospective elementary teachers, for instance, from group 1 are coded as $S_{1 \mathrm{a}}$ and $\mathrm{S}_{1 \mathrm{~b}}$.

As prospective elementary teachers, they are going to be classroom teachers who teach not only mathematics but also other integrated subjects, such as science, social science and the Indonesian language. They have already completed all the courses offered in the study programme. There are 7 courses related to mathematics education (18 credits/12.5\%), namely: 1) Fundamental mathematics for elementary schools I, 2) Fundamental mathematics for elementary school II, 3) Mathematics education for the lower grades of elementary school, 4) Mathematics Education for the upper grades of elementary school, 5) Statistics for education, 6) Capita selecta of mathematics (e.g. problem solving and modeling in mathematics) and, and 7) Indonesian realistic mathematics education (Putra, 2019b). The last two courses are optional, but prospective elementary teachers have to choose one of these. The concept of rational numbers was presented in the course of fundamental mathematics for elementary school I, and the instruction related to learning and teaching rational numbers was given to prospective elementary teachers in the course of mathematics education for the upper grades of elementary school in the second year of their study, where the analysed textbook was a manual for this course. This means that prospective elementary teachers have sufficient mathematical and didactic knowledge of operations with rational numbers. The data for this study consist of participants' written answers and video recordings. These data were analysed in terms of mathematical and didactic praxeology. The analysis focuses on prospective elementary teachers' techniques and the technological-theoretical discourse appearing during their collaborative work. The mathematical techniques were coded from prospective elementary teachers' written answers, and the didactic techniques were interpreted from their explanation in the discussion of how to explain mathematical techniques to students. Then, prospective elementary teachers' mathematical and didactic technologies were interpreted from their justifications of the given techniques. For example, prospective elementary teachers mention that they need to change two fractions into a common denominator to add the two fractions because the two fractions have to be the same unit fraction. This is the mathematical technology to justify the mathematical technique of adding two fractions. 
The terminology mentioned by the prospective elementary teachers indicates the mathematical and didactic theory--for instance, when a prospective teacher provides an explanation that learning fractions should relate to students' daily life activities. This explanation can be seen as reflecting realistic mathematics education theory (Freudenthal, 1991). The data analysis was done by the author, and passages indicating mathematical and didactic praxeology were reviewed several times. The passages containing questionable points were discussed with two mathematics education researchers who are familiar with the content and context of the study. Then, prospective elementary teachers' mathematical and didactic praxeology were compared to the PRM of the textbook analysis to study the extent of the didactic transposition.

\section{Results}

The results of this study are presented in two sections. First, I describe the praxeological analysis of the arithmetic operations of rational numbers appearing in the textbook. The second part presents prospective elementary teachers' collaborative work on HT'Ts concerning the mathematical and didactical praxeology being discussed in pairs.

\section{Knowledge to be taught: Praxeology from the textbook for teacher education}

The topic of rational numbers is presented in a section called "Fractions" from pages 51 to 66. The section is divided into ten subsections (Table 1) and followed by three tasks at the end of this section. Decimals are presented as a part of fractions and introduced through converting fractions into decimals and vice versa. The arithmetic operations of rational numbers cover two-thirds of the topics.

The textbook presents two mathematical techniques on how to convert fractions into decimals. The techniques are described as follows:

$\tau_{1 \mathrm{f} \rightarrow \mathrm{d}}$ : change a fraction into a fraction with the denominator of the power of ten and then convert it into a decimal by putting the comma to the numerator based on the number of zero digits on the denominator. e.g. $\frac{13}{25}=\frac{13 \times 4}{25 \times 4}=\frac{52}{100}=0.52$ $\tau_{2 \mathrm{f} \rightarrow \mathrm{d}}$ : use long division to find the quotient; this technique is also known as a standard division algorithm. 
In contrast, to convert a decimal into a fraction, the technique presented in the textbook is the opposite of $\tau_{1 \mathrm{f} \rightarrow \mathrm{d}}$, and can be described as follows:

$\tau_{1 \mathrm{~d} \rightarrow \mathrm{f}}$ : change the decimal into a decimal fraction and then simplify it.

Table 1: Topics of rational numbers presented in the textbook.

\begin{tabular}{|c|c|c|}
\hline Subsection & Topics & Sub topics \\
\hline 1 & Definition of fractions & \\
\hline 2 & Equivalent fractions & \\
\hline 3 & Comparing fractions & \\
\hline 4 & Simplifying fractions & \\
\hline \multirow{3}{*}{5} & \multirow{3}{*}{ Converting fractions } & $\begin{array}{l}\text { Converting fractions to percentages and vice } \\
\text { versa }\end{array}$ \\
\hline & & Converting fractions to decimals and vice versa \\
\hline & & $\begin{array}{l}\text { Converting decimals to percentages and vice } \\
\text { versa }\end{array}$ \\
\hline \multirow{4}{*}{6} & \multirow{4}{*}{ Adding fractions } & Adding fractions with common and \\
\hline & & uncommon denominators \\
\hline & & Adding decimals \\
\hline & & Adding fractions and decimals \\
\hline \multirow{4}{*}{7} & \multirow{4}{*}{ Subtracting fractions } & Subtracting fractions with common and \\
\hline & & uncommon denominators \\
\hline & & Subtracting decimals \\
\hline & & Subtracting fractions and decimals \\
\hline \multirow{4}{*}{8} & \multirow{4}{*}{$\begin{array}{l}\text { Multiplication } \\
\text { fractions }\end{array}$} & Multiplying an integer and a fraction \\
\hline & & Multiplying two fractions \\
\hline & & Multiplying an integer and a mixed fraction \\
\hline & & Multiplying decimals \\
\hline \multirow{4}{*}{9} & \multirow{4}{*}{ Division of fractions } & Dividing an integer by a fraction \\
\hline & & Dividing a fraction by an integer \\
\hline & & Dividing a fraction by a fraction \\
\hline & & Dividing decimals \\
\hline 10 & Proportion and scale & \\
\hline
\end{tabular}

The textbook provides no technology-theoretical discourse to justify those techniques, but it can be implied that the equivalent value between fractions and decimals is the technological justification for those techniques; the value between two different representations, such as $\frac{13}{25}$ and 0.52 , remains the same. 


\section{Adding fractions and decimals}

The types of mathematical tasks presented in the textbook begin from adding two unit fractions with a common denominator $\left(T_{1 f+}\right.$, e.g., $\left.\frac{1}{4}+\frac{1}{4}\right)$. This is followed by adding fractions with uncommon denominators $\left(T_{2 f+}\right)$ and adding mixed fractions $\left(T_{3 f+}\right)$. The mathematical techniques suggested for solving these mathematical tasks are presented, respectively, as follows:

$\tau_{1 f+}$ : represent each fraction into a circle representation, shade each circle based on the given fraction, and then combine both representations into a circle representation.

$\tau_{2 f}:$ change both fractions into fractions with a common denominator and then add the numerators.

$\tau_{3 f+}:$ add the integers and the fractions separately and then combine them (e.g., $4 \frac{5}{12}+$ $\left.3 \frac{3}{12}=(4+3) \frac{5+3}{12}=7 \frac{8}{12}=7 \frac{2}{3}\right)$.

$\tau_{2 f+}$ is a general mathematical technique for solving any type of task involving adding of fractions. The textbook gives no technological-theoretical explanation to justify those techniques, but one can infer that the definition of a fraction, that a fraction is defined as a part of a whole, and a fraction as a number is written as $\frac{a}{b}, b \neq 0$, becomes the theory to justify these techniques.

The textbook also presents how to add two decimals after presenting the praxeology for adding fractions. The textbook presents a standard mathematical technique by adding the digits of the two decimals based on their place value $\left(\tau_{1 d^{+}}\right)$to solve the type of mathematical task of adding two decimals $\left(T_{1 d^{+}}\right)$. Even though the textbook gives no technology, one can infer place value as the general theory behind this praxeology.

\section{Subtracting fractions and decimals}

To the case of subtracting fractions, the textbook states that the mathematical techniques used to subtract fractions are the same as those for adding fractions. This is followed by presenting three types of subtraction task: subtracting two unit fractions with a common denominator $\left(T_{1 f}\right.$, e.g., $\left.\frac{3}{4}-\frac{1}{4}\right)$; subtracting fractions with uncommon denominators $\left(T_{2 f}\right)$ and subtracting mixed fractions $\left(T_{3 f}\right)$. These tasks 
correspond to the mathematical techniques $\tau_{1 f}$, $\tau_{2 f}$, and $\tau_{3 f}$, respectively, within explanations similar to what has been presented in the mathematical techniques for adding fractions. For instance, to solve $\frac{3}{4}-\frac{1}{4}$, the textbook presents a circle diagram to represent $\frac{3}{4}$ (dividing the circle into four equal parts and shading three parts to represent $\frac{3}{4}$ ), then presents another circle for $\frac{1}{4}$, and states that $\frac{3}{4}$ minus $\frac{1}{4}$ equals $\frac{2}{4}$ (by presenting a circle diagram with four equal parts, two of which are shaded). Similarly, the textbook presents a type of task about subtracting two decimals $\left(T_{1 d}\right)$, and the mathematical technique for this task is similar to that for adding decimals (coded as $\left.\tau_{1 d-}\right)$.

\section{Multiplying fractions and decimals}

The textbook presents three types of mathematical tasks: multiplying an integer and a fraction $\left(T_{1 f \times}\right)$; multiplying two fractions $\left(T_{2 f \times}\right)$, and multiplying an integer and a mixed fraction $\left(T_{3 f \times}\right)$. Two mathematical techniques are presented related to these tasks, as follows:

$\tau_{1 f \times}:$ use a rectangular model to represent fraction multiplication as an area of a rectangle.

$\tau_{2 f}:$ use a standard algorithm for multiplication of fractions (e.g., $\frac{a}{b} \times \frac{c}{d}=\frac{a c}{b d}$ ).

Concerning $T_{2 f \times}$, the textbook gives the example of $\frac{3}{4} \times \frac{5}{6}$. Figure 3 shows how the mathematical technique $\tau_{1 f \times}$ works, and how it connects to $\tau_{2 f \times}$.

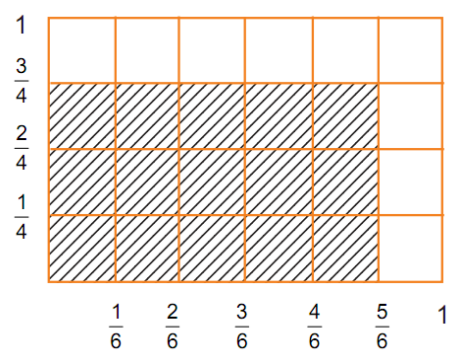

Figure 3: A rectangle model of multiplication of fractions.

Figure 3 is followed by the explanation that there are 15 shaded square units out of 24 square units, so $\frac{3}{4} \times \frac{5}{6}=\frac{15}{24}$. 
Two mathematical techniques are proposed to solve the task type of multiplication of decimals $\left(T_{1 d x}\right)$. The first technique is to convert decimals into fractions and then multiply the two fractions $\left(\tau_{1 d x}\right)$. The second technique is to multiply two decimals as multiplication of integers, and at the end, place the comma into the multiplication result based on the sum of numbers of digits from the two decimals $\left(\tau_{2 d x}\right)$. There is no technological-theoretical discourse mentioned in the textbook to justify these techniques.

\section{Dividing fractions and decimals}

Three types of mathematical task about dividing fractions are presented in the textbook. The first type of task is the division of an integer by a fraction $\left(T_{1 f=}\right)$. This is followed by the task of dividing a fraction by an integer $\left(T_{2 f}\right)$. The last type of task is the division of a fraction by a fraction $\left(T_{3 f}=\frac{a}{b} \div \frac{c}{d}\right)$. The textbook presents two mathematical techniques for solving the first two types of task. The first technique is to use a rectangle model $\left(\tau_{11_{-}}\right)$, and the second technique is called an algebraic technique $\left(\tau_{2 f}\right)$. Both techniques are illustrated by the task of $5 \div \frac{1}{2}$.

Concerning $\tau_{1 f}$, the textbook presents 5 squares and then divides each square into 2 parts. Under the drawings, there is a text explaining that each square consists of 2 halves, so 5 squares consists of $5 \times 2$ halves that equals to 10 halves. While the algebraic technique $\left(\tau_{2 f}\right)$ is described as follows:

$$
t_{2 f \div}: 5 \div \frac{1}{2}=n \text {, find } n
$$

Solution: $\frac{2}{1} \times \frac{1}{2}=1$, so $5 \times\left(\frac{2}{1} \times \frac{1}{2}\right)=5$

$$
\begin{gathered}
\left(5 \times \frac{2}{1}\right) \times \frac{1}{2}=5 \\
\left(5 \times \frac{2}{1}\right)=5 \div \frac{1}{2} \\
5 \div \frac{1}{2}=10 \\
n=10
\end{gathered}
$$

Thus, the technique $\tau_{3 f}: \frac{a}{b} \div \frac{c}{d}=\frac{a}{b} \times \frac{d}{c}$ has been proven, and it can be applied to all types of fraction division tasks. 
To solve the third type of task, the textbook gives a standard algorithm for dividing fractions $\left(\tau_{3 f-}\right)$ that is built upon the technique $\tau_{2 f-}$. The technique $\left(\tau_{3 f-}\right)$ is commonly called the invert-and-multiply rule for dividing fractions. The technological discourse to justify technique $\tau_{1 f}$ for a task of type $T_{1 f}$ seems to differ from a task of type $T_{2 f}$. Quotative division is the technological discourse underlying the use of technique $\tau_{1 f-}$ for the task of type $T_{1 f}$, and partitive division is used to justify the use of technique $\tau_{1 f \div}$ for a task of type $T_{2 f \div}$.

Two mathematical techniques are proposed for solving the task type involving division of decimals $\left(T_{1 d^{-}}\right)$, and these are similar to what has been presented for the task of type $T_{1 d x}$. The first technique is to convert decimals into fractions and then to divide the two fractions $\left(\tau_{1 d^{-}}\right)$. The second technique is to divide two decimals as a division of integers $\left(\tau_{2 d}\right)$; first, change the divisor into an integer by multiplying the divisor and the dividend by the power of ten; after that, apply the standard algorithm of division to get the quotient. There is no technological-theoretical discourse mentioned in the textbook to justify these techniques.

Taught knowledge: Prospective elementary teachers' mathematical and didactic praxeology Praxeological analysis of HTT 1

HTT 1 consists of mathematical and didactic tasks. These tasks derive from the tasks of type $T_{2 f+}$ and $T_{2 f}$ and can be written as $t_{2 f}: \frac{2}{3}+\frac{1}{2}$ and $t_{2 f}: \frac{4}{7}-\frac{1}{3}$. The didactic tasks proposed in the second and third questions can be described as follows:

$Q_{2} \rightarrow t_{d l, f f}$ : give your interpretations of pupils' incorrect mathematical technique for $t_{2 f+}$,

and $t_{d l f}$ is coded as the didactic task for the subtraction of fractions.

$Q_{3} \rightarrow t_{d 2, f}$ : propose strategies to help pupils solve the mathematical task $t_{2 f+}$, and provide some explanation or justification for the given techniques, and $t_{d 2, f}$ indicates the didactic task for the subtraction of fractions.

Of the 32 prospective elementary teachers, 30 gave correct answers to the mathematical tasks $t_{2 f+}$ and $t_{2 f}$. All of them applied the mathematical techniques $\tau_{2 f+}$ and $\tau_{2 f}$, respectively. 
One prospective teacher also provided an alternative mathematical technique using the rectangle model $\left(t_{1 f^{+}}\right)$to solve the addition task $\left(\tau_{2 f+}\right)$, and she confirmed that a similar technique could be used to solve the subtraction task $\left(t_{2 f}\right)$. Two prospective elementary teachers could not give correct answers, although they tried to employ the mathematical techniques $\tau_{2 f+}$ and $\tau_{2 f}$. They did not know how to find an equivalent fraction (Figure 4), although they might have realised that the two fractions could not be added or subtracted if the denominators were not the same.

$$
\begin{aligned}
& \frac{2}{3}+\frac{1}{2}=\frac{2}{6}+\frac{1}{6}=\frac{3}{6} \\
& \frac{4}{7}-\frac{1}{3}=\frac{4}{21}-\frac{1}{21}=\frac{3}{21}
\end{aligned}
$$

Figure 4: A prospective teacher's written answer to mathematical tasks $\mathrm{t}_{2 \mathrm{f}+}$ and $\mathrm{t}_{2 \mathrm{f} \text {. }}$

Prospective elementary teachers' interpretation of the mathematical task $t_{2 f}$ and $t_{2 f}$ was related to their judgment that pupils should simply add and subtract fractions as they did with integers. This justification was written by 9 prospective elementary teachers. For instance, a prospective teacher from group 3 (coded as $S_{3 a}$ ) wrote: The answers given by those pupils are wrong because they solve the tasks based on the common addition [and subtraction] operations of [integers].... When the pupils find these types of task, they will directly solve using the common addition [and subtraction] operations. Therefore, it is necessary to explain the appropriate techniques. Three prospective elementary teachers wrote that pupils did not know the meaning or concept of fractions. The pupils should consider that fractions are different from integers, and the operations of addition and subtraction of fractions are not similar to the techniques used for addition and subtraction of integers. Meanwhile, 26 prospective elementary teachers wrote that the pupils need to understand the procedural techniques for adding and subtracting fractions. They proposed mathematical techniques $\tau_{2 f+}$ and $\tau_{2 f-}$ to teach pupils. For instance, this can be illustrated by the written answer from $\mathrm{S}_{4 \mathrm{a}}$ :

We have to teach pupils to understand the addition operation of fractions--that they cannot directly add those numbers, but they have to change both fractions into fractions with a common denominator. 
Additionally, two prospective elementary teachers wrote that a teacher needs to explain contextual situations or number lines to the pupils. However, they provided no further explanation or technological justification for how to employ those didactic techniques.

In the peer discussion, it is evident that all prospective elementary teachers agreed to teach pupils the mathematical techniques $\tau_{2 f+}$ and $\tau_{2 f}$, and this didactic technique is coded as direct instruction in the standard mathematical techniques $\left(\tau_{2 f+}{ }^{*}\right.$ and $\tau_{2 f}$ *). It is shown by the discussion between a pair in the following excerpt.

$\mathrm{S}_{3 \mathrm{~b}}$ : In my opinion, pupils have to know, for instance, what a denominator is.

$\mathrm{S}_{3 \mathrm{a}}$ : The concept.

$S_{3 b}$ : Eh, the concept of fractions, which one is the denominator.

$\mathrm{S}_{3 \mathrm{a}}$ : Yes.

$\mathrm{S}_{3 \mathrm{~b}}$ : On the top or the bottom?

$\mathrm{S}_{3 a}$ : Which one is the numerator?

$\mathrm{S}_{3 \mathrm{~b}}$ : It is not possible $3+2=5$, so both fractions have to be changed into fractions with a common denominator. That is the technique. What do you think?

$S_{3 a}$ I also did it like that. It means for fractions with uncommon denominators; we have to change them into fractions with common denominators. The denominators are the numbers at the bottom, aren't they?

$\mathrm{S}_{3 \mathrm{~b}}: \mathrm{Hmm}$.

$\mathrm{S}_{3 \mathrm{a}}$ : After that, both fractions can be added.

$S_{3 b}$ : If some pupils still do not understand because fractions are complicated topics.

$S_{3 a}$ If some pupils do not understand, we can come closer to their desks.

$\mathrm{S}_{3 \mathrm{~b}}$ : Guide them one by one.

$S_{3 a}$ : But, it has to be specific when explaining mathematics. When I taught mathematics, I used to explain it many times.

Both prospective elementary teachers agree to instruct pupils based on the standard algorithm. The discussion mainly focuses on how to change both fractions into fractions with a common denominator. This technique conforms to what is presented in the textbook $\left(\tau_{2 f}\right)$. Both prospective elementary teachers hardly mention technological discourse to justify the technique. 
Mastering the standard procedure is known as a conceptual understanding of fractions, and it seems that they rely on this as a theoretical justification for the operations of adding and subtracting fractions. In addition, explaining the standard techniques personally and re-explaining those techniques often become general didactical techniques for teaching mathematics.

Three pairs of participants suggested alternative didactic techniques for teaching addition and subtraction of fractions. Two pairs suggested explaining the meaning of fractions before the pupils learn how to add fractions. For instance, $S_{12 a}$ mentioned that pupils need to know that a fraction consists of a numerator and a denominator, and the operations of adding and subtracting fractions are different from those for multiplication and division of fractions. Teachers need to support pupils in understanding the different algorithms for the operations of fractions. The technological-theoretical discourse described by $\mathrm{S}_{12 a}$ relied on what appears in the textbook for student teachers. Meanwhile, only $S_{1 a}$ proposed a didactic technique based on a concrete model. She suggested explaining the meaning of adding and subtracting fractions using rectangle models, but she did not really use the model to show how the common denominator appears as a consequence of combining both fractions (Putra, 2018).

\section{Praxeological analysis of HTT 2}

HTT 2 consists of two types of mathematical tasks. The tasks belong to $T_{1 d \times}$ and $T_{d_{d *}}$, respectively, which can be described as $t_{d d \times}: 0.25 \times 8$ and $t_{d d^{\circ}}: 8 \div 0.25$. The didactical tasks associated with the two tasks can be defined as follows:

$t_{d l, d \times}$ : what teachers can do to support pupils' understanding so that the result of mathematical task $t_{1 d \times}$ is smaller than 8 .

$t_{d l, d \div}$ : what teachers can do to support pupils' understanding so that the result of mathematical task $t_{1 d}$ is bigger than 8 .

To solve the tasks presented in HTT2, most prospective elementary teachers sought the correct answers. Among sixteen pairs, three pairs did not give sufficient praxeology for both tasks. They wrote no mathematical techniques on their worksheets and just discussed general ideas that sometimes did not support pupils' understanding of the didactic tasks. The following excerpts illustrate this: 
$\mathrm{S}_{4 \mathrm{a}}$ : We tell the pupils that the result of any number multiplied by 0 must be 0 even though one uses a calculator. It does not mean the calculator is broken.

$\mathrm{S}_{4 \mathrm{~b}}$ : It becomes confusing. If the calculator is not broken, why is the result like that? $\mathrm{S}_{4 \mathrm{a}}$ : The rule is like that.

$\mathrm{S}_{4 \mathrm{~b}}$ : The mathematics rule.

$\mathrm{S}_{4 \mathrm{a}}$ : The pupils are confused, and I am also confused (Laugh). Indeed, I am also confused.

Although $\mathrm{S}_{4 \mathrm{~b}}$ mentioned "the mathematics rule", she did not give any further justification of what it means. Limited mathematical knowledge of rational numbers becomes a major challenge for them to construct enough mathematical and didactic praxeology. Table 2 presents the summary of correct mathematical techniques proposed by prospective elementary teachers to the mathematical tasks of HTT 2. The most common mathematical technique for both tasks was to change decimals into fractions and then apply the standard algorithm for the multiplication of fractions $\left(\tau_{1 d x}\right)$ or for the division of fractions $\left(\tau_{1 d-}\right)$. However, the number of techniques for both tasks was not the same. This indicates that prospective elementary teachers handled the two tasks differently.

One of the commonalities (Table 2) among thirteen pairs in discussing the second HTT was to instruct pupils directly from these mathematical techniques.

Table 2: A summary of prospective elementary teachers' mathematical techniques for solving $\mathrm{t}_{1 \mathrm{~d} \times}$ and $\mathrm{t}_{2 \mathrm{~d} \div}$

\begin{tabular}{lclc}
\hline \multicolumn{1}{c}{ Mathematical techniques for $t_{1 d \times}$} & $\mathrm{n}$ & \multicolumn{1}{c}{ Mathematical techniques for $t_{d, d \div}$} & $\mathrm{n}$ \\
\hline $\begin{array}{l}\text { Use the standard algorithm for } \\
\text { multiplication of decimals }\end{array}$ & $3 \begin{array}{l}\text { Convert both numbers into integers, } \\
\text { and then apply the standard } \\
\text { algorithm of integers }\end{array}$ & 2 \\
\hline $\begin{array}{l}\text { Change decimals into fractions, and } \\
\text { then apply the standard algorithm for } \\
\text { multiplication of fractions }\end{array}$ & $6 \begin{array}{l}\text { Change decimals into fractions, and } \\
\text { then apply the standard algorithm } \\
\text { for division of fractions }\end{array}$ & 10 \\
\hline Use ratio or proportional reasoning & 3 & Use inverse proportion & 2 \\
\hline $\begin{array}{l}\text { Use multiplication as repeated } \\
\text { addition }\end{array}$ & 4 & Use division as repeated subtraction & 0 \\
\hline Total & 16 & Total & 14 \\
\hline
\end{tabular}

They agreed with the standard techniques without offering further justification. 
However, many pairs had difficulty, particularly with the division task, because they struggled to explain the meaning behind the standard algorithm for division of fractions. Table 3 presents a summary of prospective elementary teachers' didactic techniques.

Table 3: A summary of prospective elementary teachers' didactic techniques for solving $t_{\mathrm{d} 1, \mathrm{~d} x}$ and $t_{\mathrm{d} 1, \mathrm{~d} \div}$

\begin{tabular}{llll}
\hline Didactic techniques for $t_{d 1, d \times}$ & $\mathrm{n}$ & Didactic techniques for $t_{d 1, d \div}$ & $\mathrm{n}$ \\
\hline $\begin{array}{l}\text { Instruct pupils directly using the } \\
\text { standard algorithm for multiplication of } \\
\text { decimals }\end{array}$ & $\begin{array}{l}\text { Ask pupils to convert both numbers } \\
\text { into integers and then explain the } \\
\text { division algorithm for integers. }\end{array}$ & 2 \\
\hline $\begin{array}{l}\text { Ask pupils to change decimals into } \\
\text { fractions, and then explain the standard } \\
\text { algorithm for multiplication of fractions }\end{array}$ & $\begin{array}{l}\text { Ask pupils to change decimals into } \\
\text { fractions, and then explain the } \\
\text { standard algorithm for division of } \\
\text { fractions }\end{array}$ & 10 \\
\hline $\begin{array}{l}\text { Explain using ratio or proportional } \\
\text { reasoning }\end{array}$ & 3 & Explain using inverse proportion & 2 \\
\hline $\begin{array}{l}\text { Explain to pupils based on the meaning } \\
\text { of multiplication as repeated addition }\end{array}$ & 4 & $\begin{array}{l}\text { Explain based on a contextual } \\
\text { problem/real life situation through } \\
\text { which pupils can experience the } \\
\text { division of a fraction/decimal }\end{array}$ & 2 \\
\hline Total & $\begin{array}{l}\text { Provide pupils with a simple } \\
\text { problem. e.g. } 8 \div 4 \text {, and ask them to } \\
\text { think and link to the given task. }\end{array}$ & 2 \\
\hline & 16 & Total & 17 \\
\hline
\end{tabular}

A common didactic technique suggested by prospective elementary teachers during their collaborative work was to instruct pupils directly based on the mathematical techniques $\tau_{1 d \times}$ and $\tau_{1 d \div}$. They tended to agree with both techniques without offering any technological or theoretical discourse. This is illustrated by the discussion from group 1:

$\mathrm{S}_{1 \mathrm{a}}$ : Well, it is just like this. We explain that 0.25 equals $\frac{25}{100}$.

$\mathrm{S}_{1 \mathrm{~b}}$ : Yes.

$\mathrm{S}_{1 \mathrm{a}}:\left[\frac{25}{100}\right]$ is multiplied by 8 . So here is the result (points to the answer on her worksheet). After that, 8 divided by 0.25 , and it equals $\frac{25}{100}$ (the statement followed by $\left.\mathrm{S}_{1 \mathrm{~b}}\right)$. 
So, when it is the division of fractions, the sign of [division] becomes multiplication, and the divisor is reversed. It ends.

It is obvious that they provided no justification for the standard algorithm, particularly the division algorithm of fractions. The rule in the algorithm is something that pupils need to follow without knowing what it means or how it arises. They do not seem to relate to the manner in which the textbook explains the issue. Besides instructing pupils directly on the standard algorithm for multiplication of decimals, another common didactic technique suggested by prospective elementary teachers was to explain the meaning of multiplication as repeated addition, and it was commonly followed by ratio or proportional reasoning to explain the didactic task of $t_{d l, d x}$. However, prospective elementary teachers did not apply a similar idea to explain the didactic task of $t_{d l, d}$. This can be seen from a discussion between the prospective elementary teachers in group 2 .

$S_{2 a}$ : Let's try, for example, multiplication is repeated addition.

$\mathrm{S}_{2 \mathrm{~B}}$ : Oh, yes. Multiplication is repeated addition, so it is 8 times 0.25 ; add 0.25 , add 0.25 until 8 times.

$\mathrm{S}_{2 \mathrm{~A}}$ : Yes.

$\mathrm{S}_{2 \mathrm{~B}}$ : So, division is repeated subtraction, isn't it? Why is the result 32?

$\mathrm{S}_{2 \mathrm{~A}}$ : No, not like that. It is just for multiplication.

Both prospective elementary teachers agreed to teach pupils the meaning of multiplying rational numbers by repeated addition for the multiplication task but not by repeated subtraction for the division task. This could have been caused by the result of the division task, which is greater than the two operators, and it seems to contradict the technology discourse for the division of integers. Then, both prospective elementary teachers continued their discussion to construct another didactic praxeology based on ratio and proportion.

$S_{2 a}$ : Like this. For example, if half of 8 is equal to 4 , a quarter of 8 is equal to 2 .

$\mathrm{S}_{2 \mathrm{~B}}$ : A quarter of 8 is equal to 2 .

$\mathrm{S}_{2 \mathrm{~A}}$ : Yes, it is a quarter, isn't it? 0.25 .

$\mathrm{S}_{2 \mathrm{~B}}$ : Yes. Ok, that is our logic. So, how can we explain it to pupils who do not yet understand it?

$\mathrm{S}_{2 \mathrm{~A}}$ : Yes. We first explain it based on [multiplication and division of] fractions. 
$S_{2 a}$ could make a link between ratio and multiplication, but she did not mention or discuss the similar idea for handling the didactic task of $t_{d t, d \neq}$.

In addition, the ratio and proportion-based didactic technique seems to be an alternative after the pupils learn the standard algorithm for multiplication of fractions.

There were three alternative didactic techniques discussed by prospective elementary teachers to explain the didactic task of $t_{d, d, d \div}$ (Table 3). One was to explain the division task using a contextual or real life situation. Group 13 discussed this idea using the context of sharing cakes.

$\mathrm{S}_{13 \mathrm{~b}}$ : I think like this, because it is eaaa $0, \ldots$ For the division task, it might be true that the result is more than [8], and 8 is divided by 0.25 . Assuming there are, for example, 8 pieces of cake (She drew 8 circles). $4,5,7$, and 8 .

$\mathrm{S}_{13 a}: \mathrm{Hmm}$.

$\mathrm{S}_{13 \mathrm{~b}}$ : 0.25 is equal to a quarter. This means $4,4,4,4,4,4,4$, and 4 (She divides each circle into 4 pieces described in figure 5). The total is 32 .
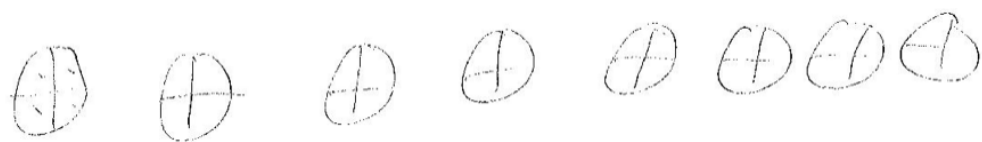

Figure 4: Diagram representations for the task of fraction division

$\mathrm{S}_{13 \mathrm{a}}: 1,2,3,4,5,6$, and so on (He pointed and counted each slice of the circles). Isn't it?

The technological-theoretical discourse behind the contextual situation proposed by $\mathrm{S}_{13 \mathrm{a}}$ could be quotative division. It was indicated by the idea of finding how many quarters of cake were in 8 whole cakes. This theory is effective for completing a division task involving a divisor smaller than 1 . Concerning those mathematical and didactic techniques discussed by prospective elementary teachers, many prospective elementary teachers proposed techniques with insufficient technological and theoretical discourse. For instance, none of the prospective elementary teachers explained why one needs to change the sign of division into multiplication when 
doing division operations on fractions. Many prospective elementary teachers mentioned only that it was a rule they had learnt, and the pupils needed to apply similar techniques. Some prospective elementary teachers could provide a general technological-theoretical discourse to explain why the multiplication yields an answer smaller than 8 , while division gives an answer greater than 8 . This explanation corresponds to a general mathematical theory related to multiplication and division with rational numbers.

\section{Didactic Transposition from knowledge to be taught to taught knowledge}

The analysis of knowledge to be taught was based on what mathematical praxeology was presented in the textbook. The investigation of this study showed that the textbooks presented 4 types of tasks for each domain (addition, subtraction, multiplication and division of rational numbers), and one type of task was related to the operation of decimals. Meanwhile, the textbooks propose four techniques to solve the tasks of adding and subtracting rational numbers, and one of the techniques was specified for adding and subtracting of decimals. There were also 4 techniques for multiplication of rational numbers and 5 techniques for division of rational numbers. There were different numbers of techniques between the two domains because the textbook also presents algebraic techniques for fraction division. In addition, there was no explicit technological-theoretical discourse presented in the textbook to justify the practical block. Concerning taught knowledge, the tasks given to prospective elementary teachers formed part of the tasks presented in the textbook. The techniques suggested by these prospective elementary teachers were mostly dominated by common mathematical techniques based on the standard algorithm of adding and subtracting fractions, using fraction conversion to decimals, and then applying the standard algorithm for decimals to solve the multiplication and division tasks. Prospective elementary teachers proposed some alternative mathematical techniques, such as using ratio or proportional reasoning for the multiplication task or using inverse proportion for the division task. The didactic techniques were mostly based on their mathematical techniques, and instructing pupils directly using standard algorithm was the common didactic technique discussed. Meanwhile, the prospective elementary teachers mentioned some technological-theoretical discourse to justify their practical block. One of common technological discourses was to explain that fractions were different from integers, and the operations of addition and subtraction of fractions 
were not similar to the techniques used in the addition and subtraction of integers. Moreover, instructing pupils directly from those mathematical techniques became prospective elementary teachers' concern in building their didactic praxeology. From the explanation above, I inferred that the praxeology presented in the textbook concentrates more on praxis than logos. On the other hand, prospective elementary teachers also focused their discussion on praxis based on their experiences and on school textbooks, but some prospective elementary teachers could create alternative techniques to solve the tasks and relate these to didactic techniques to instruct the students. Meanwhile, the textbook offered almost no explicit technologicaltheoretical discourse as compared to prospective elementary teachers' discourses founded on their belief in teaching rational numbers as a process to explain the standard techniques.

\section{Discussion and Conclusion}

The present study sought answers to three research questions. First, it investigated what knowledge to be taught appears in the mathematical textbooks for teacher education; second, what taught knowledge was discussed by prospective elementary teachers during their collaborative work; and the third aim was to explain the relation between knowledge to be taught and taught knowledge. Regarding the first research question, the study shows that the textbook focuses only on presenting the mathematical tasks and techniques to solve those tasks. The common mathematical techniques proposed are based on the standard algorithm for fractions; then, they use conversion of fractions to decimals, and then apply the standard algorithm for decimals to solve the mathematical tasks. In supporting the standard mathematical techniques for the four operations, the textbook provides some didactic situations related to the use of diagrams or rectangle models, but how these can be implemented to construct pupils' mathematical knowledge of operations with fractions and decimals is not presented in detail. Indeed, one can say that the textbook still invokes the traditional approach for presenting the knowledge of rational numbers to be taught, and this is probably a standard model for mathematical textbooks in Indonesia (Wijaya et al., 2015; Wijayanti \& Winsløw, 2017). 
Wijaya et al., (2015), for instance, found that only about 10\% of the tasks in the school textbooks are context-based tasks, and only $2 \%$ of the contextual tasks are reflection tasks, which are considered as the tasks with the highest level of cognitive demand. We may argue that there is a commonality among mathematical textbooks in Indonesia in that they focus more on the formal mathematical tasks together with the standard techniques or algorithms. However, textbooks play an essential role in the design of instruction (Alajmi, 2012). It is necessary to present sufficient praxeology in the textbooks, especially those for teacher education. The lack of mathematical technologies and theories presented in Indonesian textbooks could hinder prospective elementary teachers from dealing with advanced tasks such as division of fractions or decimals. Concerning the second research question, prospective elementary teachers focused on discussing the standard algorithm or techniques to solve the four operations of rational numbers. Especially with the tasks of adding and subtracting fractions, all pairs agreed to instruct pupils directly using the standard algorithm, and only a few participants suggested alternative mathematical and didactic techniques. It is also evident that most prospective elementary teachers discussed the didactic task of $t_{d 2, f^{+}}$and $t_{d 2, f}$ based on the written answers given to the mathematical task of $t_{2 f+}$ and $t_{2 f}$. Therefore, they always mention that instructing students using the standard algorithm is a strategy to support student understanding of the concept of operations with rational numbers. What they may believe is contrary to the theory of mathematics education, which is developing today in the direction of realistic mathematics education (RME) (Freudenthal, 1991) or the theory of the "didactical situation" (Brousseau, 2002). Within those theories, learning mathematics is seen as a meaningful human activity, and real-life situations need to be an inseparable part of the process of mathematization. Similarly, prospective elementary teachers also propose standard techniques for solving mathematical tasks in HTT 2, and then instruct their pupils based on those techniques. Although some prospective elementary teachers do suggest alternative mathematical and didactic techniques, many still consider that the standard algorithm for multiplication and division of fractions constitutes the central praxeology for pupils to succeed in such tasks. Moreover, a lack of questioning of other ideas leads them to limit their discussion related to didactic technologies and theories. This condition has also been found in previous studies on prospective teachers' knowledge of rational numbers (Alenazi, 2016; Depaepe et al., 2015; Ma, 1999; Newton, 2008; Putra, 2016; Putra \& Winsløw, 2018). 
Prospective teachers' lack of mathematical knowledge leads them to experiences challenges in constructing didactic knowledge for teaching students (Depaepe et al., 2015). Many prospective elementary teachers failed to find a sufficient explanation to justify the standard techniques, especially in the case of division of rational numbers. In addition, the learning instruction given during teacher training was insufficient to support teachers' mathematical knowledge of rational numbers (Newton, 2008; Widjaja, Stacey, \& Steinle, 2008).Based on the explanation to the first and second research questions, the relation between knowledge to be taught and taught knowledge is clearly visible. Prospective elementary teachers transpose what mathematical knowledge about operations of rational numbers presented in the textbook to the mathematical and didactic tasks presented in each HTT. They mostly apply standard mathematical techniques, such as $\tau_{1 d \times}$ for the multiplication of fractions, and $\tau_{1 d-}$ for the division of fractions, and also consider modelling their didactic praxeology on that mathematical praxeology. It seems that the institution has lost the rationale behind the knowledge of rational numbers that is to be taught, and the learning process becomes 'monumentalistic' education, in which students, in this case prospective elementary teachers, are invited to contemplate bodies of knowledge, the rationale for which has perished over time (Chevallard in Bosch \& Gascón, 2006). Of course, the occurrence of this transposition process could be caused by many factors, one of which could be the 'noosphere' in which the textbook author constructs the knowledge about the operation of rational numbers for the teacher education program. In addition, prospective elementary teachers' previous mathematical knowledge gained during their time at school could be the reason for the mathematical and didactical knowledge shared by these prospective elementary teachers. Finally, we conclude in this study that prospective Indonesian teachers create their mathematical and didactic praxeology based on standard techniques or procedures rather than on conceptual or theoretical discourse. Many prospective elementary teachers experience some difficulty and challenge in giving a justification for such a didactic situation as appears in each HTT. This situation is supported by the praxeology presented in the textbook; prospective elementary teachers are likely to transpose what mathematical knowledge they have learned during their time in teacher education. The implication of this study is that a textbook used in teacher education needs to emphasize not only the practical aspects but also the theoretical aspects. For example, in a textbook it is insufficient to present only an algorithm about the division of fractions; instead, the meaning behind that 
algorithm should also be addressed. While prospective elementary teachers need an adequate background in mathematics, especially in the field of numbers and their operations, this should function to support them in developing better didactic praxeology. Since this study focuses only on the textbook and the teachers' mathematical knowledge shared during their collective work on two HTTs, I suggest conducting a further study to investigate how the textbook is used by teacher educators to instruct student teachers in a course related to this topic. Such a study could provide more detail about the didactic transposition process of knowledge to be taught into taught knowledge. In addition, this study has a limitation in terms of representation of rational numbers because the tasks focus only on one task about adding and subtracting fractions and another about multiplication and division of decimals. Therefore, a further study needs to address this limitation by designing more types of tasks with several representations of rational numbers.

\section{References}

Alajmi, A. H. (2012). How do elementary textbooks address fractions? A review of mathematics textbooks in the USA, Japan, and Kuwait. Educational Studies in Mathematics, 79(2), pp. 239261. https://doi.org/10.1007/s10649-011-9342-1

Alenazi, A. (2016). Examining middle school pre-service teachers' knowledge of fraction division interpretations. International Journal of Mathematical Education in Science and Technology, 47(5), pp. 696-716. https://doi.org/10.1080/0020739X.2015.1083127

Austin, P., Carbone, R. E., \& Webb, P. (2011). Prospective primary school teachers' attempts to pose acceptable word problems on the addition of fractions: Some insights from South Africa and the United States of America. African Journal of Research in Mathematics, Science and Technology Education, 15(2), pp. 168-178. https://doi.o-rg/10.1-080/10288457.2011.10740710

Bosch, M., \& Gascón, J. (2006). Twenty-Five Years of the Didactic Transposition. ICMI Bulletin, 58, pp. 51-65.

Brousseau, G. (2002). Theory of Didactical Situations in Mathematics. New York: Kluwer Academic Publisher.

Charalambous, C. Y., \& Pitta-Pantazi, D. (2007). Drawing on a theoretical model to study students' understandings of fractions. Educational Studies in Mathematics, 64(3), pp. 293-316. https://doi.org/10.1007/s10649-006-9036-2

Chevallard, Y. (1985). La transposition didactique. Grenoble: La pensée sauvage.

Chevallard, Y. (2006). Steps towards a new epistemology in mathematics education. In M. Bosch (Ed.), Proceedings of the IV Congress of the European Society for Research in Mathematics Education (pp. 2130). Grenoble: La Pensée Sauvage.

Chevallard, Y. (2007). Readjusting Didactics to a Changing Epistemology. European Educational Research Journal, 6(2), pp. 131-134. https://doi.org/10.2304/eerj.200-7.6.2.131

Chevallard, Y., \& Bosch, M. (2014). Didactic transposition in mathematics education. In Encyclopedia of Mathematics Education (pp. 170-174). Springer Netherlands. 
Depaepe, F., Torbeyns, J., Vermeersch, N., Janssens, D., Janssen, R., Kelchtermans, G., ... Van Dooren, W. (2015). Teachers' content and pedagogical content knowledge on rational numbers: A comparison of prospective elementary and lower secondary school teachers. Teaching and Teacher Education, 47, pp. 82-92. https://doi.o-rg/10.1016/j.tate.2014.12.009

Freudenthal, H. (1991). Revisiting Mathematics Education: China lecturers. Dordrecht: Kluwer Academic Publishers.

Graeber, A. O., \& Tirosh, D. (1988). Multiplication and division involving decimals: Preservice elementary teachers' performance and beliefs. The Journal of Mathematical Behavior, 7(3), pp. 263-288.

Graeber, A. O., Tirosh, D., \& Golver, R. (1989). Preservice teachers' misconceptions in solving verbal problems in multiplication and division. Journal for Reseach in Mathematics Education, 20(1), pp. 95-102.

Hill, H. C., Schilling, S. G., \& Ball, D. L. (2004). Developing Measures of Teachers' Mathematics Knowledge for Teaching. The Elementary School Journal, 105(1), pp. 11-30. https://doi.org/10.1086/428763

Isiksal, M., \& Cakiroglu, E. (2011). The nature of prospective mathematics teachers' pedagogical content knowledge: The case of multiplication of fractions. Journal of Mathematics Teacher Education, 14(3), pp. 213-230. https://doi.org/10.1007/s10857-010-9160-x

Johar, R., Patahuddin, S. M., \& Widjaja, W. (2017). Linking pre-service teachers' questioning and students' strategies in solving contextual problems: A case study in Indonesia and the Netherlands. The Mathematics Enthusiast, 14(1-3), pp. 101-128. https://doi.org/10.1242/dmm.009688

Kara, F., \& Incikab1, L. (2018). Sixth grade students' preferences on multiple representations used in fraction operations and their performance in their preferences. Elementary Education Online, 17(4), pp. 2136-2150. https://doi.org/10.17051/ilkonline.20-19.506984

Kastberg, S., \& Morton, C. (2014). Mathematical content knowledge for teaching elementary mathematics: A focus on decimals. The Mathematics Enthusiast, 11(2), pp. 311-332.

Li, H. C. (2014). A comparative analysis of British and Taiwanese students' conceptual and procedural knowledge of fraction addition. International Journal of Mathematical Education in Science and Technology, 45(7), pp. 968-979. https://doi.org/10.108-0/0020739X.2014.892163

Lundberg, A. L. V., \& Kilhamn, C. (2018). Transposition of Knowledge: Encountering Proportionality in an Algebra Task. International Journal of Science and Mathematics Education, 16(3), pp. 559-579. https://doi.org/10.1007/s10763-016-9781-3

Ma, L. (1999). Knowing and Teaching Elementary Mathematics: Teachers' understanding of fundamental mathematics in China and the United States. Mahwah, NJ.: Lawrence Erlbaum Associates.

Newton, K. J. (2008). An Extensive Analysis of Preservice Elementary Teachers' Knowledge of Fractions. American Educational Research Journal, 45(4), pp. 1080-1110. https://doi.org/10.3102/0002831208320851

Pansell, A., \& Boistrup, L. B. (2018). Mathematics teachers' teaching practices in relation to textbooks: Exploring praxeologies. The Mathematics Enthusiast, 15(3), pp. 541-562.

Putra, Z. H. (2014). Pendidikan matematika SD kelas tinggi [Mathematics education for upper grade elementary school]. Pekanbaru: Unpublished textbook.

Putra, Z. H. (2016). Pengetahuan mahasiswa pedidikan guru sekolah dasar dalam merepresentasikan operasi pecahan dengan model persegi panjang [Prospective elementary teachers' knowledge in representing operation of fraction using rectangular models]. Jurnal Elemen, 2(1), pp. 1-13. https://doi.org/10.2940-8/jel.v2i1.174

Putra, Z. H. (2018). A praxeological analysis of pre-service elementary teachers' knowledge of rational numbers. Recherches En Didactique Des Mathematiques, 38(3), pp. 315-364.

Putra, Z. H. (2019a). Elementary teachers' knowledge on fraction multiplication: An anthropological theory of the didactic approach. Journal of Teaching and Learning in Elementary Education, 2(1), pp. 47-52. https://doi.org/http://dx.doi.org/10.3-3578/jtlee.v2i1.6964 
Putra, Z. H. (2019b). Praxeological change and the density of rational numbers: The case of pre-service teachers in Denmark and Indonesia. Eurasia Journal of Mathematics, Science and Technology Education, 15(5), pp. 1-15. https://doi.org/10.29333/ejmste/105867

Putra, Z. H. H., \& Winsløw, C. (2018). Teachers' collective knowledge: The case of equivalent fractions. Journal of Physics: Conference Series, 1088(1), pp. 1-6. https://doi.org/10.1088/17426596/1088/1/012003

Sembiring, R. K., Hadi, S., \& Dolk, M. (2008). Reforming mathematics learning in Indonesian classrooms through RME, 40, pp. 927-939. https://doi.org/10.1-007/s11858-008-0125-9

Senk, S. L., Tatto, M. T., Reckase, M., Rowley, G., Peck, R., \& Bankov, K. (2012). Knowledge of future primary teachers for teaching mathematics: An international comparative study. ZDM International Journal on Mathematics Education, 44(3), pp. 307-324. https://doi.org/10.1007/s11858-012-0400-7

Siegler, R. S., \& Lortie-Forgues, H. (2017). Hard Lessons: Why Rational Number Arithmetic Is So Difficult for So Many People. Current Directions in Psychological Science, 26(4), pp. 346-351. https://doi.org/10.1177/0963721417700129

Tirosh, D., \& Graeber, A. O. (1989). Elementary teachers' explicit beliefs about multiplication and division. Educational Studies in Mathematics, 20(1), pp. 79-96.

van Steenbrugge, H., Lesage, E., Valcke, M., Desoete, A., Steenbrugge, H. Van, Lesage, E., Desoete, A. (2014). Preservice elementary school teachers' knowledge of fractions: A mirror of students' knowledge? Journal of Curriculum Studies, 46(1), pp. 138-161. https://doi.org/10.1080/00220272.2013.839003

Widjaja, W., Stacey, K., \& Steinle, V. (2008). Misconceptions about density of decimals: Insights from Indonesian pre-service teachers' work. Journal for Science and Mathematics for Education in Southeast Asia, 31(2), pp. 117-131.

Wijaya, A., van den Heuvel-Panhuizen, M., \& Doorman, M. (2015). Opportunity-to-learn contextbased tasks provided by mathematics textbooks. Educational Studies in Mathematics, 89, pp. 4165. https://doi.org/10.1007/s10649-015-9595-1

Wijayanti, D., \& Winsløw, C. (2017). Mathematical practice in textbooks analysis: Praxeological reference models, the case of proportion. Journal of Research in Mathematics Education, 6(3), pp. 307-330. https://doi.org/10.17583/redi-mat.2017.2078

\section{Author}

\section{Zetra Hainul Putra, PhD}

Assistant professor, University of Riau, Faculty of Teacher Training and Education, Gedung B2, Kampus Bina Widya Km. 12.5 Simpang Baru Pekanbaru 28293 - Indonesia, e-mail: zetra.hainu@lecturer.unri.ac.id

Docent, Univerza v Riau, Fakulteta za usposabljanje in izobraževanje učiteljev, Gedung B2, Kampus Bina Widya Km. 12.5 Simpang Baru Pekanbaru 28293 - Indonesia, e-pošta: zetra.hainu@lecturer.unri.ac.id 